\title{
Plant Association of Lanternflies (Hemiptera: Fulgoridae) from Malaysian Borneo
}

\author{
AHMAD IRFAN ABDUL RAZAK*, SITI NURLYDIA SAZALI, RATNAWATI HAZALI \\ \& FARAH NABILLAH ABU HASAN AIDIL FITRI
}

\author{
Faculty of Resource Science and Technology, Universiti Malaysia Sarawak, 94300 Kota Samarahan, Sarawak, \\ Malaysia \\ Corresponding author: irfanrzks@gmail.com \\ Received: 30 October 2020 \\ Accepted: 21 December 2020 \\ Published: 31 December 2020
}

\begin{abstract}
The family Fulgoridae is known for their distinct morphological structures and striking colouration. Despite so, comprehensive documentation of insect-plant interaction from this charismatic family is greatly scarce. Presented here are records of plant association across four species of Fulgoridae from Malaysian Borneo. The current study was based on voucher specimens and field samplings from selected localities in Sarawak and Sabah, Malaysian Borneo. A total of 11 species of plants belonging to 11 genera and nine families were recorded. Three fulgorid species namely Penthicodes quadrimaculata, Pyrops intricatus and Py. sultanus shares the same host plant being the mata kucing fruit tree (Dimocarpus longan ssp. malesianus). The most speciose insect-plant association belongs to $P e$. farinosa and $P y$. sultanus with six species documented. This is the first record of host plants reported for Py. intricatus, Pe. farinosa and Pe. quadrimaculata in Malaysian Borneo.
\end{abstract}

Keywords: Fulgoridae, host plant, insect-plant association, Malaysian Borneo, Sabah, Sarawak

Copyright: This is an open access article distributed under the terms of the CC-BY-NC-SA (Creative Commons Attribution-NonCommercial-ShareAlike 4.0 International License) which permits unrestricted use, distribution, and reproduction in any medium, for non-commercial purposes, provided the original work of the author(s) is properly cited.

\section{INTRODUCTION}

The Fulgoridae or lanternflies is a family of homopteran bugs known for their striking colouration and head ornamentation. Despite these charismatic traits, little is known of their biology particularly on insect-plant associations. The group was assumed to feed on dicotyledonous trees in tropical forests (Wilson \& Wheeler, 1992). Nagai and Porion (1996) stated that very few Fulgoridae have been reported to be of any economic importance, Rhabdocephala brunnea on Baccharis sarothroides, Phrictus diadema on Theobroma cacao (Malvaceae), Phrictus quinquepartitus on Terminalia oblonga (Combretaceae), Enchophora sanguinea on Simarouba amara (Simaroubaceae), Fulgora laternaria on Hymenaea courbaril (Fabaceae), Amycle pinyonae on Pinus monophylla (Pinaceae) and Pyrops candelaria on Dimocarpus longan (Sapindaceae) and Mangifera indica (Anacardiaceae).
The family Fulgoridae lacks documentation on records of host plants. Very little is known on the possible hosts of Fulgoridae as they are rarely seen feeding on trees (Goemans, 2006). Most species do not seem to be host plant specific but obtain nourishment from several vegetable species (Nagai \& Porion, 1996). Eastop (1972) stated that tropical sap feeding insects are ought to be polyphagous. Johnson and Foster (1986) on the other hand found that some fulgorid species might be monophagous and are very selective of tree species even in a diverse forest. There are few known host plants associated with Fulgoridae, mostly from Sapindales (Bourgoin, 2020). Until recently, Pyrops sultanus was only known to feed on wild rambutans (Nephelium spp.) and tarap (Artocarpus odoratissimus) (Bosuang et al., 2017). The aim of this study is to provide new host records for Fulgoridae from Malaysian Borneo. Presented here are records of plant associations for the species Penthicodes farinosa, Pe. quadrimaculata, Py. 
intricatus and Py. sultanus based on voucher specimens from Malaysian Borneo.

\section{MATERIALS AND METHODS}

The present study was based on voucher specimens from the following institutions: 1) UNIMAS Insect Reference Collection, Sarawak (UIRC); 2) Research, Development and Innovation Division of Forest Department Sarawak, Sarawak (RDID); 3) Sabah Parks Natural History Museum, Sabah (SPM); 4) Institute for Tropical Biology and Conservation, Sabah (ITBC); and 5) Sabah Museum, Sabah (SM). Field samplings were conducted in selected localities in Sarawak. The methods used for collecting fulgorids include aerial net and modified Pennsylvanian light trap. Species identification was done using Nagai and Porion (1996) and Bosuang et al. (2017). Distribution map was generated using SimpleMappr (Shorthouse, 2010) based on their local distributional range.

\section{RESULTS}

A total of $27(5.93 \%)$ out of 455 individuals of fulgorid specimens were noted with host records. The Research, Development and Innovation Division of Forest Department Sarawak (RDID) was the only institution in Malaysian Borneo that provides information on host plants for the sampled specimens. Four species of Fulgoridae from two genera were documented with host plant records consisting of nine families, 11 genera and 11 species (Table 1).

\section{Pyrops intricatus (Walker, 1857)}

(Figure 1)

Materials examined. MALAYSIA: Sarawak: Niah, Kpg. Tg. Berlipat, 20 May 1980, Mercer and Suhaili, Dimocarpus longan ssp. malesianus (Mata kucing fruit tree), 1 우 (FN80-0640), $1 \overbrace{}^{\Uparrow}$ (FN800641) (RDID); Samunsam, Wildlife Sanctuary, 21 September 1982, Ento Team, Nephelium maingayi (Serait fruit tree), 1ठิ (FN82-0460) (RDID).

Plant associations. Dimocarpus longan ssp. malesianus (Mata kucing fruit tree) and Nephelium maingayi (Serait fruit tree).

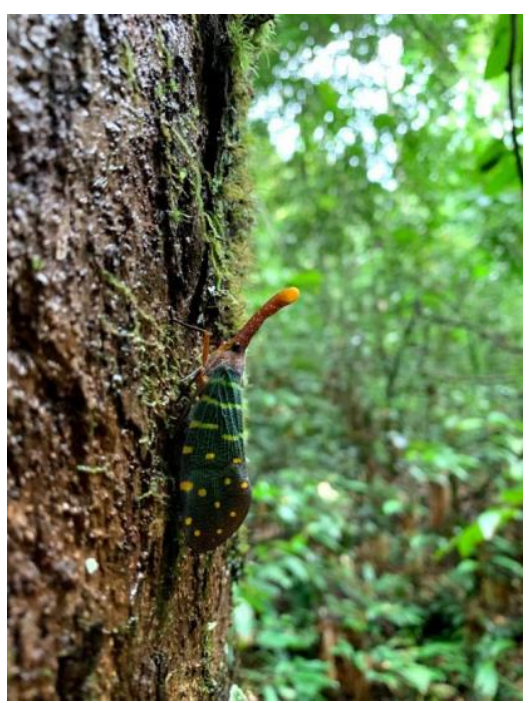

Figure 1. Lateral view of Pyrops intricatus perching on an unidentified tree (Photograph by: Marcellinus Isaac Stia Dominic)

Table 1. List of fulgorid species and plant associations of Malaysian Borneo

\begin{tabular}{|c|c|c|c|}
\hline Species & Host family & Host plant & $\begin{array}{l}\text { Number of } \\
\text { individuals }\end{array}$ \\
\hline \multirow[t]{6}{*}{ Penthicodes farinosa } & Fabaceae & Acacia mangium & 7 \\
\hline & & Albizzia falcataria & 6 \\
\hline & Arecaceae & Cocos nucifera (Coconut tree) & 2 \\
\hline & Simaroubaceae & Quassia borneensis (Medang pahit tree) & 1 \\
\hline & Ebenaceae & Diospyros maingayi (Merpinang Daun Besar tree) & 1 \\
\hline & Lamiaceae & Premna foetida (Singkil tree) & 3 \\
\hline Penthicodes quadrimaculata & Sapindaceae & Dimocarpus longan ssp. malesianus (Mata kucing fruit tree) & 1 \\
\hline \multirow[t]{2}{*}{ Pyrops intricatus } & Sapindaceae & Dimocarpus longan ssp. malesianus (Mata kucing fruit tree) & 1 \\
\hline & & Nephelium maingayi (Serait fruit tree) & 1 \\
\hline \multirow[t]{6}{*}{ Pyrops sultanus } & Meliaceae & Aglaia tomentosa (Langsat hutan fruit tree) & 1 \\
\hline & Moraceae & Artocarpus integer (Temedak fruit tree) & 1 \\
\hline & & Artocarpus odoratissimus (Tarap fruit tree)* & - \\
\hline & Dipterocarpaceae & Shorea sp. (Meranti tree) & 1 \\
\hline & Sapindaceae & Dimocarpus longan ssp. malesianus (Mata kucing fruit tree) & 1 \\
\hline & & Nephelium spp. (wild rambutans fruit tree)* & - \\
\hline
\end{tabular}

Note: * Information obtained from Bosuang et al. (2017) 
Distribution. Endemic to Borneo (Kalimantan and Sarawak only).

Local distribution. Sarawak (Niah, Samunsam, Serian, Semengoh, Tatau, Julau, Lambir Hills National Park, Balul, Batu Keling, Batu Kalo, Long Murum, Julau Nanga Jepiu, Ulu Katibas, Kota Samarahan, Bau, Sri Aman and Gunung Gading National Park) (Figure 5).

\section{Penthicodes farinosa (Weber, 1801)}

(Figure 2)

Materials examined. MALAYSIA: Sarawak: Sibu, Oya Road Nursery, 9 December 1976, A. A. Hamid, Acacia mangium (Akasia tree), 1ㅇ (FN00319) (RDID); Sabal FR, 17 May 1984, Isa

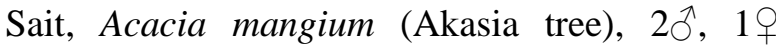
(RDID); Sabal FR, 17 May 1984, Manis Lintang, Acacia mangium (Akasia tree), $1 \hat{\jmath}$ (RDID); Sabal FR, 20 May 1984, A. A. Hamid, Acacia mangium (Akasia tree), 1 ㅇ (RDID); Sabal FR, 21 May 1984, Manis Lintang, Acacia mangium (Akasia tree), 1 우 (RDID); Sibu, Oya Road Nursery, 3 June 1979, C. W. L. Mercer, Albizzia falcataria (Batai tree), $2 \hat{\delta}$ (FN.79-0160, FN.79-0163), 2 ㅇ (FN.79-0159, FN.79-0161) (RDID); Sibu, Oya Road Nursery, Butterfly Garden, 4 July 1979, A. A. Hamid, Handpick, Albizzia falcataria (Batai tree), 2 ㅇ (FN79-52) (RDID); Semengoh, Agriculture Research Centre, 24 December 1979, Suhaili, Albizzia falcataria (Batai tree), 1 우 (FN79-0914) (RDID); Kpg. Spaoh, Coconut Garden, 6 October 1980, Mercer, Lippa and Rahman, Cocos nucifera (Coconut tree), 10ิ (FN.80-1764), 1우 (FN801765) (RDID); Simunjan Kanan, Sg. Jitak, 29 September 1980, Mercer, Lippa and Rahman, Quassia borneensis (Medang pahit tree), $1{ }^{\lambda}$ (FN.80-1481) (RDID); Tatau, Sg. Selitut, 11 May 1981, Mercer, Lippa and Suhaili, Diospyros maingayi (Merpinang Daun Besar tree), 19 (FN810244) (RDID); Kpg. Spaoh, 6 October 1980, Mercer, Lippa and Rahman, Premna foetida (Singkil tree), 3 ㅇ (FN.80-1766-FN.80-1768) (RDID).

Plant associations. Acacia mangium (Akasia tree), Albizzia falcataria (Batai tree), Cocos nucifera (Coconut tree), Quassia borneensis (Medang pahit tree), Diospyros maingayi (Merpinang Daun Besar tree) and Premna foetida (Singkil tree).

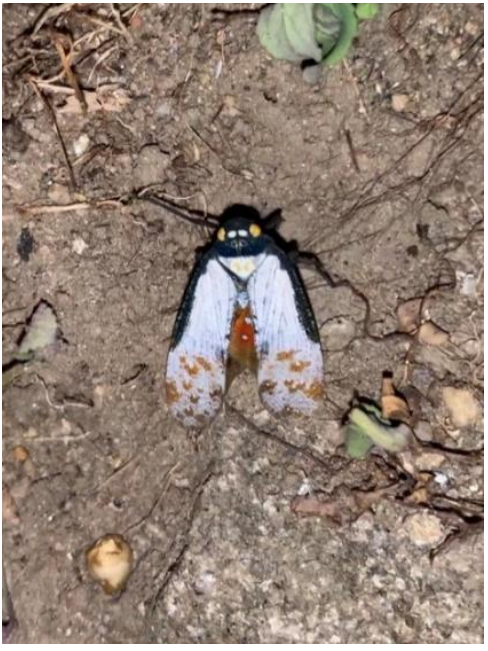

Figure 2. Dorsal view of Penthicodes farinosa on the ground preparing for flight (Photograph by: Marcellinus Isaac Stia Dominic)

Distribution. India, Myanmar, Peninsular Malaysia, Java, Sumatra, Sulawesi, the Philippines and Borneo.

Local distribution. Sarawak (Kota Samarahan, Sri Aman, Batu Kawah, Ranchan Recreational Park, Matang, Santubong, Kpg. Tanah Putih, Bau, Kota Samarahan, Sibu, Bako National Park, Semengoh Agriculture Research Centre, Simunjan Kanan, Kpg. Spaoh, Sibu, Tatau, Mukah, Niah, Sabal Forest Reserve, Sampadi Forest Reserve, Bintulu, Sebuyau, Kuching, Sarikei, Kelingkang, Lambir Hills National Park, Jelalong, Tanjung Datu, Sabal, and Gedong) and Sabah (Sorinsim, Sipitang, Hutan Epulun, Kota Kinabalu, Klias Peat Swamp Forest Field Centre Beaufort, Maliau Basin and Beluran) (Figure 5).

\section{Pyrops sultanus (Adam and White, 1847)}

(Figure 3)

Materials examined. MALAYSIA: Sarawak: Niah, Sg. Sekaloh, 17 May 1980, Mercer and Suhaili, Aglaia tomentosa (Langsat hutan fruit tree), Handpick, 2ㅇ (FN80-0588, FN80-0589) (RDID); Niah, 18 May 1980, Mercer and Suhaili, Artocarpus integer (Temedak fruit tree), 1 ㅇ (FN80-0611) (RDID); Niah, Gunung Sabis, 15 May 1980, Mercer and Suhaili, Shorea sp. (Meranti tree), 1ㅇ (FN80-0588) (RDID); Niah, Kpg. Tanjong Berlipat, 23 May 1980, Mercer and Suhaili, Dimocarpus longan ssp. Malesianus (Mata kucing fruit tree), 2 ㅇ (FN80-0719, FN80-0720) (RDID). 


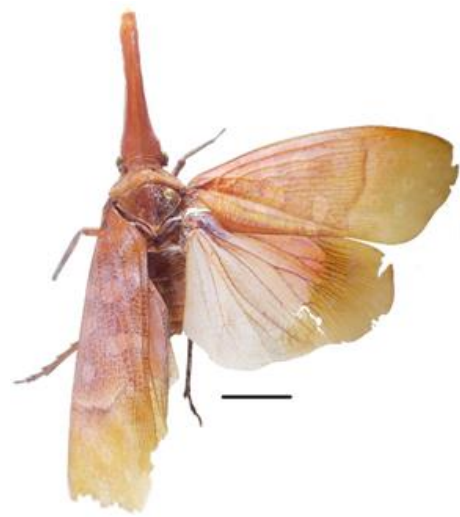

Figure 3. Dorsal view of Pyrops sultanus,, . Scale $=10$ $\mathrm{mm}$

Plant associations. Aglaia tomentosa (Langsat hutan fruit tree), Artocarpus integer (Temedak fruit tree), Shorea sp. (Meranti tree), Nephelium sp. (wild rambutan fruit tree), Dimocarpus longan ssp. malesianus (Mata kucing fruit tree) and Artocarpus odoratissimus (Tarap fruit tree).

Distribution. Endemic to Borneo.

Local distribution. Sarawak (Gunung Serapi, Gunung Sabis, Niah, Kuching, Mulu National Park, Hose Mountain, Kota Samarahan, Tanjung Datu National Park, Gunung Pueh and Tama Abu) and Sabah (Papar, Crocker Range National Park, Ranau, Kinabalu National Park, Tawau Hills Park, Kota Belud, Poring Hot Spring, Kota Belud, Kota Marudu, Sembulan, Keningau, and Inanam) (Figure 5).
Penthicodes quadrimaculata Lallemand, 1963

(Figure 4)

Material examined. MALAYSIA: Sarawak: Niah, Kpg. Tanjong Berlipat, 20 May 1980, Mercer and Suhaili, Dimocarpus longan ssp. Malesianus (Mata kucing fruit tree), Handpick, 19 (FN. 80-0642) (RDID).

Plant association. Dimocarpus longan ssp. malesianus (Mata kucing fruit tree).

Distribution. Java, Sumatra and Borneo.

Local distribution. Sarawak (Niah and Kota Samarahan) and Sabah (Kinabalu Park, Crocker Range National Park, Kota Marudu, Sipitang and Mount Trus Madi) (Figure 5).

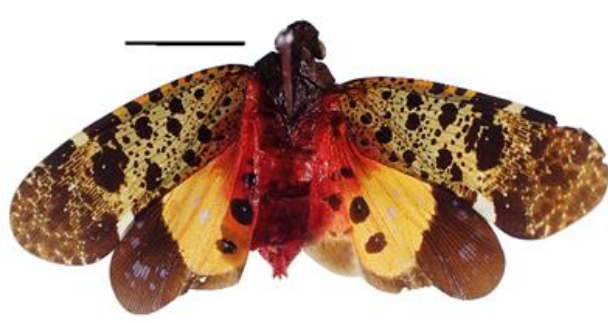

Figure 4. Dorsal view of Penthicodes quadrimaculata, ․ . Scale $=10 \mathrm{~mm}$

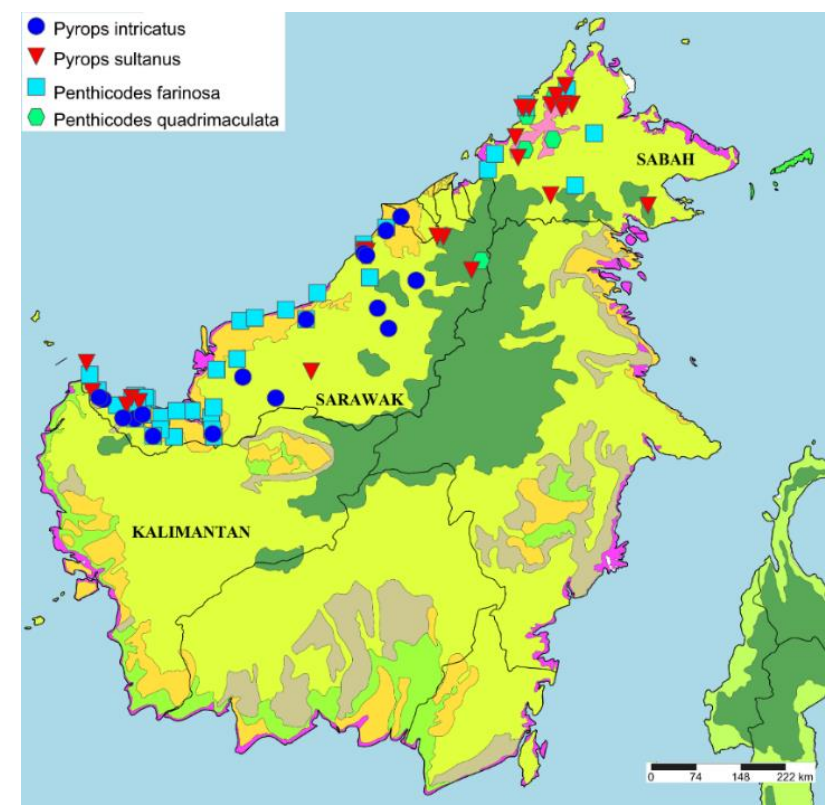

Figure 5. Distribution map of Py. intricatus, Py. sultanus, Pe. farinosa and Pe. quadrimaculata in Malaysian Borneo with background colours indicating ecoregions 


\section{DISCUSSION}

Only one host plant was recorded for the fulgorid species $P e$. quadrimaculata. Three species namely $P e$. quadrimaculata, $P y$. intricatus and $P y$. sultanus share the same host plant being the mata kucing fruit tree (Dimocarpus longan ssp. malesianus). The fulgorid species with the most abundant host plants recorded includes $P e$. farinosa and Py. sultanus, with six species documented, followed by Py. intricatus with two species, and $P e$. quadrimaculata with only one species. It must be noted that out of all five institutions sampled in Malaysian Borneo, only RDID recorded the specimens with host plants labelling. RDID has a Biodiversity (Flora) Section with a dedicated herbarium that allows identification of plants to be conducted. Fulgorid specimens collected after 1984 did not contain any host plants on the label. This may be due to its limited economic importance (Goemans, 2006; Bosuang et al., 2017), leading to shortfall in the investigation of host plants from this family.

A preliminary survey of insects at Libiki Bamboo Resort, Sarawak, in March 2019 revealed two individuals of $P y$. intricatus, sitting at an unidentified tree trunk at a height of approximately $165 \mathrm{~cm}$ from the ground. When approached, they would move to the lateral side of the tree and will only fly away to the nearest vegetation when direct contact is made. This behaviour is not unique to Fulgoridae and has also been observed in the grasshopper species Valanga nigricornis (Orthoptera: Acrididae). After a while, the same lanternflies were found to perch again at the same area of the tree throughout the survey. Our finding is supported by Goemans (2006) and O'Brien (2002) in which lanternflies tend to stay for several weeks on the same 'fulgorid tree' and comes back year after year. Some fulgorid species were found to be strongly associated with certain tree species and fidelity towards a particular tree of a given species (Hogue, 1984; Johnson \& Foster, 1986; O'Brien, 2002; Goemans, 2006). Hence, this gives the opportunity for researchers to go back and retry to capture the lanternflies when they failed on the first attempt.

There is a significant paucity in voucher specimens of Fulgoridae, particularly in Sabah.
Many specimens are represented as singletons. Identifying these hosts can help in sampling as they are notoriously known to be difficult to locate in the wild. Collections and descriptions of fulgorid nymphs of Malaysian Borneo is also scarce. RDID holds only one specimen of fulgorid nymph which is Zanna nobilis. In addition, Z. nobilis was the only species of fulgorid nymph illustrated in guidebooks dealing with the Bornean fauna (e.g. Nagai \& Porion, 1996; 2002; 2004; Bosuang et al., 2017). Knowledge on hosts can also be beneficial to the ecotourism industry. Similar to the firefly watching tourism, guides can bring visitors to the identified hosts and spectate lanternflies perching on the tree, in which guides need only to find the fulgorid tree once (O'Brien, 2002). Guides in Gunung Mulu National Park, Sarawak, for instance would know locations of these trees and include them in tours (Mason et al., 2020).

Despite not being recognised as an indicator of well-preserved forests, the presence of lanternflies may be linked with long lasting uninterrupted big or old trees (Constant \& Alisto, 2015), which is congruent with the current study. Libiki Bamboo Resort can be categorised as a secondary forest and is predominantly dominated by bamboos. The $P y$. intricatus sampled were found perching on a tall tree that is standing in the middle of a clearing. The fact that these trees are tall makes leaf collection for tree identification impossible without the appropriate equipment. This is one of the reasons why many insect specimens lack host plant documentations. To rectify this issue, collaboration with botanists is greatly essential.

According to Bosuang et al. (2017), Pe. farinosa is a common species in Borneo. This statement agrees with the current study as $P e$. farinosa was found to be the most abundant species (204 individuals) in Malaysian Borneo. In this study, this species was noted to be present in urban areas, particularly in Universiti Malaysia Sarawak, seemingly scattered all around the campus. This is likely due to their wide range of host species, classifying them as a generalist. The availability of a wider range of niche allows generalist to thrive in a range of habitats as opposed to a specialist (McPeek, 1996). Commonness of host plants can also determine phytophagous insects as common or rare (Barbosa et al., 2000; Hopkins et al., 2002). 


\section{CONCLUSION}

Host plants for Py. intricatus, Pe. farinosa and Pe. quadrimaculata are reported here for the first time. Results from this study indicate that 27 out of 455 voucher specimens examined are documented with host plants records. When based solely on voucher specimens, the hosts comprise nine families, namely Fabaceae (two species), Arecaceae (one species), Simaroubaceae (one species), Ebenaceae (one species), Lamiaceae (one species), Sapindaceae (two species), Meliaceae (one species), Moraceae (one species) and Dipterocarpaceae (one species), making a total of 11 genera and 11 species. Penthicodes farinosa and $P y$. sultanus was found to have the most speciose hosts, with six species documented. There is also a huge lack of fulgorid nymphs' specimens kept in all five repositories visited. Voucher specimens provide permanent, physical documentation of species and evidence of their occurrences at a specific point in time (Abang \& Hill, 2007). More sampling is necessary to uncover insect-plant relationship within this group. Biology, life history, behaviour, and phenology of all Fulgoridae is still undocumented and should be investigated at haste (Yap et al., 2017), considering Borneo is known for rapid deforestation due to urbanisation. With this notion in mind, future research will be plan out to further identify the hosts for this charismatic yet enigmatic family.

\section{ACKNOWLEDGEMENTS}

This study was partially funded under the Special Top-Down Grant (F07/SpTDG/1766/2018). The authors wish to thank the UNIMAS Insect Reference Collection (UIRC), Research Development and Innovation Division, Forest Department Sarawak (RDID), Sabah Parks Natural History Museum (SPM), Institute for Tropical Biology and Conservation (ITBC) and Sabah Museum (SM) for providing facilities and granting permission to examine the voucher specimens kept in the insect repository. We would also like to thank Prof. Dr. Fatimah Abang for her guidance and advice. Special thanks to Marcellinus Isaac Stia Dominic for sharing the images of lanternflies in the wild with us.

\section{REFERENCES}

Abang, F. \& Hill, D.S. (2007). Documentation of the butterfly (Lepidoptera: Rhopalocera) fauna based on voucher specimens of major depositories in Sarawak. Serangga, 12(1-2): 15-27.

Barbosa, P., Segarra, A. \& Gross, P. (2000). Structure of two macrolepidopteran assemblages on Salix nigra (Marsh) and Acer negundo L.: abundance, diversity, richness, and persistence of scarce species. Ecological Entomology, 25(4): 374-379.

Bosuang, S., Audibert, C., Porion, T. \& Chan, C.L. (2017). A guide to lanternflies of Borneo. Malaysia: Natural History Publications (Borneo). Pp. 5-110.

Bourgoin, T. (2020). Biological Interactions. Retrieved December 13, 2020, from http://hemipteradatabases.org/flow/?db=flow\&page=explorer\&card $=$ associates\&lang $=$ en.

Constant, J. \& Alisto, L. (2015). Contribution to the knowledge of some lanternflies of the Philippines (Hemiptera: Fulgoromorpha: Fulgoridae). Belgian Journal of Entomology, 27: 1-16.

Eastop, V.F. (1972). Deductions from the present day host plants of aphids and related insects. In van Emden, H.F. (ed.) Insect/ Plant Relationships. Symposium of the Royal Entomological Society of London, 16-17 September 1971, London, England. Imperial College London. Pp. 157-178.

Goemans, G. (2006). The Fulgoridae (Hemiptera, Fulgoromorpha) of Guatemala. In Cano, E. (ed.) Biodiversidad de Guatemala (Vol. 1). Guatemala, Universidad del Valle de Guatemala. Pp. 337-344.

Hogue, C.L. (1984). Observations on the plant hosts and possible mimicry models of "Lantern Bugs" (Fulgora spp.) (Homoptera: Fulgoridae). Revista de Biologia Tropical, 32(1): 145-150.

Hopkins, G.W., Thacker, J.I., Dixon, A.F.G., Waring, P. \& Telfer, M.G. (2002). Identifying rarity in insects: the importance of host plant range. Biological Conservation, 105(3): 293-307.

Johnson, L.K. \& Foster, R.B. (1986). Associations of large Homoptera (Fulgoridae and Cicadidae) and trees in a tropical forest. Journal of the Kansas Entomological Society, 59(3): 415-422. 
Mason, C.J., Walsh, B., Keller, J., Couture, J.J., Calvin, D. \& Urban, J.M. (2020). Fidelity and timing of spotted lanternfly (Hemiptera: Fulgoridae) attack patterns on ornamental trees in the suburban landscape. Environmental Entomology, 49(6): 14271436.

McPeek, M.A. (1996). Trade-offs, food web structure, and the coexistence of habitat specialists and generalists. The American Naturalist, 148: S124S138.

Nagai, S. \& Porion, T. (1996). Fulgoridae 2: Illustrated Catalogue of the Asiatic and Australian Fauna. France: Sciences Nat, Venette. Pp. 1-80.

Nagai, S. \& Porion, T. (2002). Fulgoridae 2: Supplement 1: New Fulgoridae from South-East Asia. Canterbury: Hillside Books. Pp. 1-15.

Nagai, S. \& Porion, T. (2004). Fulgoridae 2: Supplement 2: New Fulgoridae from South-East Asia. Canterbury: Hillside Books. Pp. 1-13.
O'Brien, L.B. (2002). The wild wonderful world of Fulgoromorpha. In Holzinger, W.E. (ed.) Zikaden: Leafhoppers, planthoppers, and cicadas (Insecta: Hemiptera: Auchen orrhyncha). Austria: Biologiezentrum. Pp. 83-102.

Shorthouse, David P. (2010). SimpleMappr, an online tool to produce publication-quality point maps. Retrieved December 15, 2020, from https://www.simplemappr.net.

Wilson, S.W. \& Wheeler, A.G. (1992). Host plant and descriptions of nymphs of the planthopper Rhabdocephala brunnea (Homoptera: Fulgoridae). Annals of the Entomological Society of America, 85(3): 258-264.

Yap, S.A., Kevin, A., Amarga, S. \& Constant, J. (2017). The new polillensis group in the lanternfly genus Pyrops: taxonomy, distribution and host plant (Hemiptera: Fulgoridae). Belgian Journal of Entomology, 55: 1-14. 